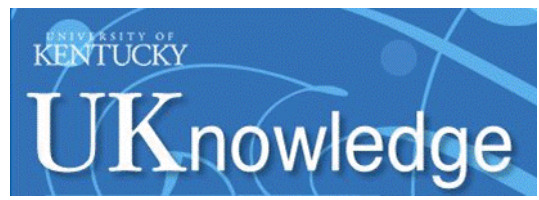

University of Kentucky

UKnowledge

\title{
Lipid Extraction from Scenedesmus sp. Microalgae for Biodiesel Production Using Hot Compressed Hexane
}

\author{
Hee-Yong Shin \\ University of Kentucky \\ Jae-Hun Ryu \\ Hanyang University, South Korea \\ Seong-Youl Bae \\ Hanyang University, South Korea \\ Czarena L. Crofcheck \\ University of Kentucky, crofcheck@uky.edu \\ Mark Crocker \\ University of Kentucky, Mark.crocker@uky.edu
}

Follow this and additional works at: https://uknowledge.uky.edu/caer_facpub

Part of the Algae Commons, Bioresource and Agricultural Engineering Commons, Chemical

Engineering Commons, and the Lipids Commons

Right click to open a feedback form in a new tab to let us know how this document benefits you.

\section{Repository Citation}

Shin, Hee-Yong; Ryu, Jae-Hun; Bae, Seong-Youl; Crofcheck, Czarena L.; and Crocker, Mark, "Lipid Extraction from Scenedesmus sp. Microalgae for Biodiesel Production Using Hot Compressed Hexane" (2014). Center for Applied Energy Research Faculty and Staff Publications. 17.

https://uknowledge.uky.edu/caer_facpub/17

This Article is brought to you for free and open access by the Center for Applied Energy Research at UKnowledge. It has been accepted for inclusion in Center for Applied Energy Research Faculty and Staff Publications by an authorized administrator of UKnowledge. For more information, please contact UKnowledge@lsv.uky.edu. 


\section{Lipid Extraction from Scenedesmus sp. Microalgae for Biodiesel Production Using Hot Compressed Hexane}

\section{Digital Object Identifier (DOI)}

https://doi.org/10.1016/j.fuel.2014.04.023

\section{Notes/Citation Information}

Published in Fuel, v. 130, p. 66-69.

(c) 2014. This manuscript version is made available under the CC-BY-NC-ND 4.0 license http://creativecommons.org/licenses/by-nc-nd/4.0/

The document available for download is the authors' post-peer-review final draft of the article. 


\title{
SHORT COMMUNICATION
}

\section{Lipid extraction from Scenedesmus sp. microalgae for biodiesel production using hot compressed hexane}

\author{
Hee-Yong Shin ${ }^{1}$, Jae-Hun Ryu², Seong-Youl Bae², Czarena Crofcheck ${ }^{3}$, Mark \\ Crocker*,1 \\ ${ }^{1}$ Center for Applied Energy Research, University of Kentucky, 2540 Research Park \\ Drive, Lexington, KY 40511, USA \\ ${ }^{2}$ Department of Chemical Engineering, Hanyang University, Ansan 426-791, Gyeonggi- \\ do, Republic of Korea \\ ${ }^{3}$ Department of Biosystems \& Agricultural Engineering, University of Kentucky, KY \\ 40506, USA \\ *Corresponding author. Tel: +1-859-257-0295; fax: +1-859-257-0220; \\ E-mail address: mark.crocker@uky.edu
}

\begin{abstract}
Lipid extraction from Scenedesmus sp. microalgae using hot compressed hexane $(\mathrm{HCH})$ was investigated. Extraction performance was evaluated near the critical point of hexane and was compared with that of hexane extraction performed at room temperature and pressure, and the Bligh and Dyer extraction method. Experimental data showed that $\mathrm{HCH}$ significantly improves the lipid yield and rate of lipid extraction compared to the use of hexane at ambient conditions. High yields of biodieselconvertible lipid fractions were rapidly achieved at the critical point of hexane, at a level comparable to that of the Bligh and Dyer method.

Keywords: lipid extraction; microalgae; hot compressed hexane; biodiesel;

Scenedesmus
\end{abstract}




\section{Introduction}

Microalgae are photosynthetic unicellular microorganisms capable of converting sunlight, water, and carbon dioxide to algal biomass. Their high photosynthetic rates enable microalgae to serve as an effective carbon capture platform while rapidly accumulating lipids in their biomass. Even in a conservative scenario, microalgae are predicted to produce about 10 times more biodiesel per unit area of land than a typical terrestrial oleaginous crop [1-4]. Since microalgal species can be cultured on non-arable land, the production of algal biomass does not place additional strains on

food production [5]. For these reasons, microalgae are currently considered some of the most promising alternative sources for biodiesel feedstock [3].

Traditionally, lipids have been extracted from biological matrices using a combination of chloroform, methanol, and water through Bligh and Dyer's method [6]. Indeed, this method has been used as a benchmark for comparing solvent extraction methods. However, it has several disadvantages when used on a large scale because it generates significant quantities of waste solvent. Organic solvent is costly to recycle and can be unsafe to handle in large amounts [7]. Therefore, although Bligh and Dyer's method has proven effective for the majority of microalgal lipid extractions, an alternative organic solvent extraction method is needed for larger scale use [8]. Hexane is the most common solvent of choice for large-scale lipid extractions due to its costeffectiveness. When extracting lipids from microalgae, hexane is less toxic than chloroform, has minimal affinity towards non-lipid contaminants and has higher 
selectivity towards neutral lipid fractions that can be converted to biodiesel using existing technology $[9,10]$. The use of hexane alone for high yield lipid extractions from microalgae would be a more economical and environmentally friendly process for biodiesel production. Unfortunately, hexane has been reported to be less efficient than chloroform-based solvent mixtures for microalgal lipid extractions [9-11].

When the temperature and pressure of fluids are raised over their critical points, fluids enter the supercritical region and demonstrate unique properties of both the liquid and gas phases. A supercritical fluid possesses a density close to that of a liquid and has the ability to dissolve many components. Simultaneously, the high diffusivity and low viscosity of supercritical fluids enable them to behave in a manner similar to gas. Due to these advantages, supercritical fluids appear well suited for use as extraction media. Indeed, lipid extractions using supercritical carbon dioxide have recently been studied extensively for biodiesel production from microalgae [12-14]. Based on these considerations, in this work lipid extraction from Scenedesmus microalgae was evaluated using hot compressed hexane $(\mathrm{HCH})$ in sub- and supercritical conditions. Crude lipid yield and the fatty acid methyl ester (FAME) yield obtained from $\mathrm{HCH}$ extracts were compared with those obtained using hexane extraction at ambient conditions and with the Bligh and Dyer extraction method. Soxhlet extraction, which is considered a baseline for the comparison of lipid extraction methods, was also tested near the boiling point of hexane.

\section{Experimental}




\subsection{Microalgae preparation and materials}

The algae used in all experiments were Scenedesmus acutus (UTEX B72).

Algae were cultured autotrophically in a 5500 L closed-loop vertical tube

photobioreactor located in a greenhouse, using a urea-based medium containing 0.14

$\mathrm{g} / \mathrm{L}$ of urea [15]. The temperature of the culture medium was not controlled and ranged

between 18 and $43{ }^{\circ} \mathrm{C}$. After harvesting and dewatering, the algae (10-15\% solids) were

dried in an oven at $60{ }^{\circ} \mathrm{C}$ for $24 \mathrm{~h}$. Algal biomass from a single harvest $(1.1 \mathrm{~kg}$ dry

weight) was used for all experiments. The dried algae ( $3 \%$ moisture content) were

subsequently ground in a coffee grinder until the algae particles were less than $150 \mu \mathrm{m}$.

After grinding and before all extraction procedures, algae were heated to $100{ }^{\circ} \mathrm{C}$ for 24

$\mathrm{h}$ to remove residual water (moisture content $<1 \%$ ). All organic solvents were reagent

grade and were used without further purification. $\mathrm{BF}_{3}$ in methanol $\left(10 \mathrm{wt} . \% \mathrm{BF}_{3}\right.$,

Sigma-Aldrich) was used for the transesterification of lipid extracts. FAME mixture

(99.9\% pure, Sigma-Aldrich) was used as a standard, and methyl heptadecanoate (17:0)

was used as an internal standard for analyzing FAME content.

\subsection{Bligh and Dyer extraction}

Lipids were extracted by mixing chloroform-methanol-deionized water (1:1:0.9, $\mathrm{v} / \mathrm{v} / \mathrm{v}$ ). This ratio is based on Bligh and Dyer's method [6]. After placing $5 \mathrm{~g}$ of algae in an Erlenmeyer flask, $25 \mathrm{ml}$ chloroform, $50 \mathrm{ml}$ methanol, and $20 \mathrm{ml}$ of deionized water were poured into the flask. The mixture was then shaken for $10 \mathrm{~min}$, after which an additional $25 \mathrm{ml}$ chloroform and $25 \mathrm{ml}$ deionized water were poured into the flask. The 
mixture was then shaken for a specified period of time. When the extraction was

finished, the mixture was immediately filtered to remove algae and avoid further lipid extraction. The mixture was transferred to a separatory funnel to allow separation of the organic and aqueous layers, after which the chloroform layer was evaporated using a rotary evaporator to leave behind the extracted lipids. The weight of extracted lipids was then recorded.

\subsection{Hexane extraction at ambient conditions}

Algae $(5 \mathrm{~g})$ and hexane $(100 \mathrm{ml})$ were placed in an Erlenmeyer flask and shaken for a prescribed time. When the extraction was complete, the mixture was filtered to remove any remaining algae. Hexane was removed with a rotary evaporator and the weight of extracted lipids was recorded.

\subsection{Hot compressed hexane extraction}

Five grams of algae were loaded into an autoclave $(300 \mathrm{ml})$ with $100 \mathrm{ml}$ of hexane. The autoclave was purged using argon gas, heated to the desired temperature $\left(220,235\right.$, or $\left.250^{\circ} \mathrm{C}\right)$, and held for either 5 or $10 \mathrm{~min}$. The pressure inside the vessel was monitored using a pressure gauge, and the agitation speed was adjusted to $300 \mathrm{rpm}$. After extraction was completed, the autoclave was cooled to room temperature and depressurized. The extracted mixture was filtered to separate algae debris, and hexane was removed with a rotary evaporator. The lipid extracts were weighed gravimetrically to obtain the crude lipid yield.

\subsection{Soxhlet extraction with hexane}


Five grams of dry algae were placed in a cellulose thimble $(25 \mathrm{~mm}$ I.D., $28 \mathrm{~mm}$ O.D., $100 \mathrm{~mm}$ length) inside the soxhlet extractor. The extraction was continued at 80 ${ }^{\circ} \mathrm{C}$ for $12 \mathrm{~h}$ using $250 \mathrm{ml}$ of hexane. After the solvent was removed, the extracted lipid was gravimetrically quantified.

\subsection{Microalgal lipid analysis}

Crude lipid yield was calculated by dividing the weight of crude lipid by the weight of dry algae. The obtained lipid (400 mg) was transesterified at $80^{\circ} \mathrm{C}$ for $2 \mathrm{~h}$ using $4 \mathrm{ml}$ of $\mathrm{BF}_{3}$ in methanol to determine FAME content. After the reaction was complete, chloroform and deionized water $(4 \mathrm{ml}$ each) were added and centrifugation was performed. The bottom layer was then collected and the solvent was evaporated. Transesterified products were analyzed by an Agilent 6890 gas chromatograph-mass spectrometer equipped with a HP-88 column (100 m length, $0.25 \mathrm{~mm}$ I.D., $0.2 \mu \mathrm{m}$ film thickness). A solution of methyl heptadecanoate in heptane $(5 \mathrm{mg} / \mathrm{ml})$ was used as the internal standard for FAME analysis. Three milliliters of internal standard solution was added to $75 \mathrm{mg}$ of transesterified products for preparation of the samples. Samples (1 $\mu 1)$ were injected at an initial oven temperature of $50^{\circ} \mathrm{C}$. After injection, the oven was heated at $10{ }^{\circ} \mathrm{C} / \mathrm{min}$ to $170{ }^{\circ} \mathrm{C}$, at $5{ }^{\circ} \mathrm{C} / \mathrm{min}$ to $210{ }^{\circ} \mathrm{C}$ and held for $10 \mathrm{~min}$, then at 5 ${ }^{\circ} \mathrm{C} / \mathrm{min}$ to $230{ }^{\circ} \mathrm{C}$ and held for $6 \mathrm{~min}$. The flow rate of carrier gas (He) was $1 \mathrm{ml} / \mathrm{min}$.

The injector and detector temperatures were set at $260{ }^{\circ} \mathrm{C}$. The ion source temperature was $280^{\circ} \mathrm{C}$, while the interface temperature was $260^{\circ} \mathrm{C}$. Electron impact (EI) mass spectra were measured at an ionizing energy of $70 \mathrm{eV}$ by scanning from 50 to $500 \mathrm{~m} / \mathrm{z}$. 
FAMEs in samples were identified by comparing the retention times of FAME peaks with those of authentic standards, and also confirmed by measuring their EI mass spectra.

\section{Results and Discussion}

Lipid extractions were carried out near the critical point of hexane $\left(235^{\circ} \mathrm{C}, 31\right.$ bar), and extraction performance was compared with that of hexane extraction at room temperature and pressure, as well as with the Bligh and Dyer method, and soxhlet extraction using hexane. Table 1 shows crude lipid yields at different extraction conditions for each method. As expected, the Bligh and Dyer method extracted a relatively large amount of lipid $(14.5 \pm 0.5 \mathrm{wt} . \%)$ within $2 \mathrm{~h}$, whereas hexane extraction at ambient conditions yielded only $4.0 \pm 0.4 \mathrm{wt} . \%$ lipids after $3 \mathrm{~h}$ of extraction time.

Soxhlet extraction with hexane proved similarly ineffective $(5.9 \pm 0.2 \mathrm{wt} . \%$ lipid yield $)$. For $\mathrm{HCH}$ extraction, the maximum yield of crude lipid was obtained within 5 min at all extraction conditions used in this study. Under subcritical conditions, corresponding to $220^{\circ} \mathrm{C}$ and 25 bar, the lipid yield was approximately $11.9 \pm 0.3 \mathrm{wt} . \%$. As temperature and pressure rose to around the critical point, lipid yield increased and reached a maximum value of $16.3 \pm 0.2 \mathrm{wt} . \%$. The crude lipid yield remained almost constant above the critical point of hexane, the yield being slightly higher than that obtained with the Bligh and Dyer method. Overall, $\mathrm{HCH}$ greatly accelerates the low extraction rate obtained with hexane at ambient conditions and provides significantly higher lipid yields. From these results, it is believe that due to the intermediate liquid-gas properties 
obtained above the critical point of hexane, $\mathrm{HCH}$ can penetrate through cellular matrices rapidly and produce a high extraction yield.

Lipids can be defined as any biological molecule that is soluble in organic solvents. Most lipids can generally be classified into two categories based on the polarity of the molecular head group [16]: (1) neutral lipids (acylglycerols, free fatty acids (FFA), hydrocarbons, sterols, ketones, and pigments such as carotenes and chlorophylls), and (2) polar lipids, which are further sub-categorized into phospholipids and glycolipids. Among the various lipid components, acylglycerols, FFA, and fatty acid parts of polar lipids are readily converted to FAMEs, which are the main components of biodiesel. This indicates that acylglycerols, FFA, and fatty acid parts of polar lipids are desirable biodiesel-convertible lipid fractions. In this study, therefore, FAME yield (as well as crude lipid yield) was used as an important index to evaluate extraction efficiency for biodiesel applications. Moreover, the fatty acid profile in the feedstock has a significant impact on the properties of the resulting biodiesel [17]. Therefore, it is important to determine the FAME composition in order to ascertain if the presence of high temperature and pressure during lipid extraction has a significant effect on the fatty acid profiles. The fatty acid profile in the crude lipid was determined by transesterifying the lipids obtained from the different extraction methods. A comparison of FAME compositions and yields for the extraction methods is shown in Table 2, from which it is evident that the FAME compositions were similar regardless of the extraction procedure. The main FAMEs in the crude lipid extracts were methyl 
esters of palmitic acid (C16:0), palmitoleic acid (C16:1), elaidic acid (C18:1t), oleic acid (C18:1c), linolelaidic acid (C18:2t), linoleic acid (C18:2c), and $\alpha$-linolenic acid (C18:3n3). The degree of unsaturation (as defined in Table 2) ranged from 151.16 to 167.04 depending on the method; the fact that the values are almost the same indicates that there was no significant thermal cracking of unsaturated FAMEs in the crude lipid in spite of the relatively high temperature and pressure during $\mathrm{HCH}$ extraction. The selectivity to FAME shown by the extract obtained using hexane at ambient conditions was higher than that of the Bligh and Dyer extract due to the relatively low solvent polarity of hexane compared to chloroform, thereby favoring the extraction of neutral lipids. However, overall FAME yield was much lower than that of the Bligh and Dyer extract. $\mathrm{HCH}$ extraction afforded somewhat lower selectivity to biodiesel-convertible lipid fractions compared to that of the Bligh and Dyer method, but FAME yield was almost the same due to the high crude lipid yield.

Based on these results, it is evident that using $\mathrm{HCH}$ as an extraction medium enormously enhanced the low efficiency of hexane for microalgal lipid extraction. As a result, high yields of biodiesel-convertible lipid fractions were achieved at short times, at a level comparable to that of the Bligh and Dyer method.

\section{Conclusions}

Lipid extraction from Scenedesmus microalgae using $\mathrm{HCH}$ was demonstrated.

The merit of this approach is that high yields of biodiesel-convertible lipid fractions can be obtained in a short time using hexane alone. $\mathrm{HCH}$ is a promising alternative medium 
for microalgal lipid extraction for biodiesel applications.

\section{Acknowledgments}

The authors thank Dr. Dae Jung Kim for assistance with preliminary

experiments and the Kentucky Department of Energy Development and Independence

for partial funding of this work.

\section{References}

1. Chisti Y. Biodiesel from microalgae. Biotechnology Advances 2007;25:294-306.

2. Rosenberg JN, Oyler GA, Wilkinson L, Betenbaugh MJ. A green light for engineered algae: redirecting metabolism to fuel a biotechnology revolution. Current Opinion in biotechnology 2008;19:430-436.

3. Sheehan J, Dunahay T, Benemann J, Roessler P. A look back at the U.S. department of energy's aquatic species program: biodiesel from algae. 1998; NREL/TP-580-24190 ed. In: Laboratory, N.R.E. (Ed.), National Renewable Energy Laboratory. US Department of Energy, pp. 1-100.

4. Shenk P, Thomas-Hall S, Stephens E, Marx U, Mussgnug J, Posten C, Kruse O, Hankamer, B. Second generation biofuels: high-efficiency microalgae for biodiesel production. BioEnergy Research 2008;20:20-43.

5. Widjaja A, Chien C-C, Ju Y.-H. Study of increasing lipid production from fresh water microalgae Chlorella vulgaris. Journal of the Taiwan Institute of Chemical Engineers 2009;40:13-20.

6. Bligh EG, Dyer WJ.. A rapid method of total lipid extraction and purification. Canadian Journal of Biochemistry and Physiology 1959;37:911-917.

7. Sahena F, Zaidul ISM, Jinap S, Karim AA, Abbas KA, Norulaini NAN, Omar AKM. Application of supercritical $\mathrm{CO}_{2}$ in lipid extraction - A review. Journal of Food Engineering 2009;95:240-253.

8. Halim R, Gladman B, Danquah MK, Webley PA. Oil extraction from microalgae for biodiesel production. Bioresource Technology 2011;102:178-185.

9. Lee SJ, Yoon BD, Oh HM. Rapid method for the determination of lipid from the green alga Botryococcus braunii. Biotechnology Techniques 1998;12:553-556.

10. Medina AR, Grima EM, Gimenez AG, Gonzalez MJI. Downstream processing of algal polyunsaturated fatty acids. Biotechnology Advances 1998;16:517-580.

11. Grima EM, Medina AR, Gimenez AG, Perez JAS, Camacho FG, Sanchez JLG. Comparison between extraction of lipids and fatty acids from microalgal biomass. J Am Oil Chem Soc 1994;71:955-959. 
12. Halim R, Gladman B, Danquah MK, Webley PA. Oil extraction from microalgae for biodiesel production. Bioresource Technology 2011;102:178-185.

13. Crampon C, Mouahid A, Toudji SA, Lepine O, Badens E. Influence of pretreatment on supercritical $\mathrm{CO}_{2}$ extraction from Nanochloropsis oculata. Journal of Supercritical Fluids 2013;79:337-344.

14. Taher H, Al-Zuhair S, Al-Marzouqi AH, Haik Y, Farid M, Tariq S. Superciritical carbon dioxide extraction of microalgae lipid: Process optimization and laboratory scale-up. Journal of Supercritical Fluids 2014;86:57-66.

15. Crofcheck C, Xinyi E, Shea A, Montross M, Crocker M, Andrews R. Influence of media composition on the growth rate of Chlorella vulgaris and Scenedesmus acutus utilized for $\mathrm{CO}_{2}$ mitigation. Journal of Biochemical Technology 2012;4:589-594.

16. Kates M. Definition and classification of lipids. Techniques of lipidology: isolation, analysis, and identification of lipids. Elsevier Science Publisher, Amsterdam; 1986.

17. Knothe G. "Designer" biodiesel: optimizing fatty ester composition to improve fuel properties. Energy \& Fuels 2008;22:1358-1364. 
Table 1. Crude lipid yields ${ }^{\mathrm{a}}(\%)$ at different extraction conditions.

\begin{tabular}{|c|c|c|c|c|c|c|c|}
\hline $\begin{array}{l}\text { Extraction } \\
\text { conditions }\end{array}$ & $5 \mathrm{~min}$ & $10 \mathrm{~min}$ & $1 \mathrm{~h}$ & $2 \mathrm{~h}$ & $3 \mathrm{~h}$ & $6 \mathrm{~h}$ & $12 \mathrm{~h}$ \\
\hline $\begin{array}{c}\text { Bligh-Dyer } \\
\left(25^{\circ} \mathrm{C}\right)\end{array}$ & - & - & $\begin{array}{c}12.8 \\
( \pm 0.7)\end{array}$ & $\begin{array}{c}14.5 \\
( \pm 0.5)\end{array}$ & $\begin{array}{c}14.5 \\
( \pm 0.6)\end{array}$ & - & - \\
\hline $\begin{array}{l}\text { Hexane } \\
\left(25^{\circ} \mathrm{C}\right)\end{array}$ & - & - & $\begin{array}{c}2.4 \\
( \pm 0.7)\end{array}$ & $\begin{array}{c}3.5 \\
( \pm 0.5)\end{array}$ & $\begin{array}{c}4.0 \\
( \pm 0.4)\end{array}$ & $\begin{array}{c}4.1 \\
( \pm 0.5)\end{array}$ & - \\
\hline $\begin{array}{c}\mathrm{HCH} \\
\left(220^{\circ} \mathrm{C}, 25 \text { bar }\right)\end{array}$ & $\begin{array}{c}11.9 \\
( \pm 0.3)\end{array}$ & $\begin{array}{c}12.0 \\
( \pm 0.2)\end{array}$ & - & - & - & - & - \\
\hline $\begin{array}{c}\mathrm{HCH} \\
\left(235^{\circ} \mathrm{C}, 31 \mathrm{bar}\right)\end{array}$ & $\begin{array}{c}16.3 \\
( \pm 0.2)\end{array}$ & $\begin{array}{c}16.1 \\
( \pm 0.3)\end{array}$ & - & - & - & - & - \\
\hline $\begin{array}{c}\mathrm{HCH} \\
\left(250^{\circ} \mathrm{C}, 40 \text { bar }\right)\end{array}$ & $\begin{array}{c}16.4 \\
( \pm 0.3)\end{array}$ & - & - & - & - & - & - \\
\hline $\begin{array}{l}\text { Soxhlet } \\
\left(80^{\circ} \mathrm{C}\right)\end{array}$ & - & - & - & - & - & - & $\begin{array}{c}5.9 \\
( \pm 0.2)\end{array}$ \\
\hline
\end{tabular}

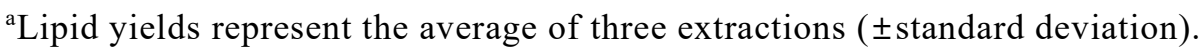


Table 2. Comparison of FAME compositions and yields for different extraction methods.

\begin{tabular}{|c|c|c|c|}
\hline & \multicolumn{3}{|c|}{ Extraction method } \\
\hline & Bligh-Dyer & Hexane & $\begin{array}{l}{ }^{\text {a}} \text { Hot compressed } \\
\text { hexane }\end{array}$ \\
\hline Extraction time (min) & 120 & 180 & 5 \\
\hline Crude lipid yield (wt.\%) & $14.5( \pm 0.5)$ & $4.0( \pm 0.4)$ & $16.3( \pm 0.2)$ \\
\hline \multicolumn{4}{|l|}{ FAME composition ( $\%$ FAME) } \\
\hline Caproic acid (C10:0) & 0.36 & 0.99 & 0.40 \\
\hline Lauric acid (C12:0) & 1.51 & 3.69 & 1.95 \\
\hline Tridecanoic acid (C13:0) & 2.56 & 4.63 & 0.59 \\
\hline Myristic acid (C14:0) & 0.36 & 0.39 & 0.43 \\
\hline Myristoleic acid (C14:1) & 1.42 & 2.80 & 1.80 \\
\hline Pentadecanoic acid (C15:0) & 0.00 & 0.00 & 0.00 \\
\hline Palmitic acid (C16:0) & 13.20 & 14.10 & 17.20 \\
\hline Palmitoleic acid (C16:1) & 4.28 & 3.79 & 5.54 \\
\hline Heptadecanoleic acid (C17:1) & 1.86 & 1.47 & 1.84 \\
\hline Stearic acid (C18:0) & 1.16 & 2.08 & 1.45 \\
\hline Elaidic acid (C18:1t) & 3.88 & 3.03 & 3.53 \\
\hline Oleic acid (C18:1c) & 6.45 & 7.66 & 8.47 \\
\hline Linolelaidic acid (C18:2t) & 13.60 & 9.75 & 10.6 \\
\hline Linoleic acid (C18:2c) & 13.80 & 13.6 & 14.5 \\
\hline$\gamma$-Linolenic acid(C18:3n6) & 0.76 & 0.85 & 0.62 \\
\hline Arachidic acid(C20:0) & 1.00 & 1.03 & 1.48 \\
\hline$\alpha$-Linolenic acid (C18:3n3) & 30.6 & 27.7 & 27.20 \\
\hline Heneicosanoic acid (C21:0) & 2.86 & 2.4 & 2.34 \\
\hline Eicosadienoic acid (C20:2) & 0.29 & 0.00 & 0.00 \\
\hline${ }^{\mathrm{b}}$ Degree of unsaturation & 167.04 & 151.16 & 154.93 \\
\hline FAME content $(\%)$ & 65.08 & 68.57 & 58.65 \\
\hline${ }^{\mathrm{c}}$ FAME yield (wt.\%) & $9.4( \pm 0.3)$ & $2.7( \pm 0.3)$ & $9.6( \pm 0.1)$ \\
\hline
\end{tabular}

${ }^{\mathrm{a}} \mathrm{HCH}$ extraction was performed at the critical point of hexane $\left(235^{\circ} \mathrm{C}, 31 \mathrm{bar}\right)$.

${ }^{\mathrm{b}}$ Degree of unsaturation $=1 \times$ monoene $(\%)+2 \times$ diene $(\%)+3 \times$ triene $(\%)+4 \times$ tetraene (\%).

${ }^{c}$ FAME yield $($ wt. $\%)=$ Crude lipid yield $($ wt. $\%) \times$ FAME content $(\%) / 100$. 